Слободанка Ж. Марковић

ОШ „Десанка Максимовић“, Звездара

markovic-s@s,sbb.rs

\title{
КУЛТУРОЛОШКИ И ЛИНГВОКУЛТУРОЛОШКИ АСПЕКТ ТЕКСТА У ОСНОВНОШКОЛСКИМ УЏБЕНИЦИМА ЗА РУСКИ ЈЕЗИК ${ }^{1}$
}

\begin{abstract}
Anстракт
Овај рад се бави истраживањем културолошки релевантних текстуалних материјала из основношколских уџбеника за руски језик. У савременој методици лингвокултурологија и настава културе разматрају се као саставни и обавезни део наставног процеса, чији значај проистиче из циљева и задатака учења страног језика, у складу са новом културолошком парадигмом, конституисаном у другој половини 90-их година , култура посредством језика, језик посредством култуpe“. Покушали смо да, на основу емпиријске анализе текстотеке актуелног уџбеничког корпуса, ${ }^{2}$ укажемо на значај једне од функција уџбеника страног језика - функције трансмисије стране културе у формирању социокултурне компетенције. У том циљу идентификовали смо, извршили процену и вредновање културолошки релевантне текстотеке са различитих становишта и за свако од њих настојали смо да наведемо и најважнија теоријска начела на којима је засновано истраживање на конкретном материјалу - уџбеницима.
\end{abstract}

Кључне речи: уџбеник, текст, култура, лингвокултурологија, трансмисија културе, социокултурна компетенција.

1 Рад је настао из дела магистарске тезе „Функција трансмисије културе у уџбеницима и приручницима руског језика за основну школу“, одбрањене у Новом Саду у октобру 2013. године.

2 Чине га две актуелне основношколске уџбеничке серије: Орбита (руски језик као обавезни изборни страни језик, учи се од петог до осмог разреда) и Родничок (руски језик као први страни језик, учи се од првог до осмог разреда). 


\section{А) УВОД}

Текст представља фундаменталну категорију теорије уџбеника и један од најзначајнијих структурних система једног уџбеника. Покушали смо да на основу теоријско-пројективне и емпиријске анализе издвојимо принципе организације уџбеничког текста који најадекватније доприносе формирању социокултурне компетенције и да понудимо конкретна конструкцијска решења дидактичког обликовања ове централне компоненте уџбеника, релевантна за постизање тога циља. Модел структуре уџбеника од којег полазимо заснован је у Зујеву и Кончаревић (Зујев 1988; Кончаревић 2002). Социокултурни аспект уџбеника за основну школу, који је предмет нашег истраживања, укључује два плана: садржински и структурно-организациони. На садржинском плану за спроведено истраживање од значаја су само поједини параметри везани за информацијски потенцијал текстуалних прилога. На структурно-организационом плану покушали смо да сагледамо типолошке одлике текста као централне компоненте макроструктуре основношколског уџбеника, који се користи као медијум за преношење културолошких и лингвокултуролошких информација и начела њиховог обликовања. Истраживање наведеног предмета доприноси стварању основа за имплементацију могућег ширег спектра конструкцијских решења при презентацији културолошких садржаја у уџбеницима руског језика.

У теорији уџбеника страних језика текст се обично схвата као релативно заокружени вербални комплекс представљен визуелним (класични уџбенички текст) или аудитивним путем. Ми ћемо, према К. Кончаревић, „под текстотеком подразумевати комплекс текстова као вербалних, писмених и звуковних саопштења““ (Кончаревић 1997: 281-297; 2002: 92). Постоје бројне класификације материјала текстотеке, које полазе од различитих критеријума, те смо, на основу оних који су релевантни за наше истраживање, сагледали конкретни текстуални материјал којим располажемо.

Типологија текстова. У нашим разматрањима пошли смо од типологије текста коју је, према усмерености ка одређеном циљу наставе и основним функцијама текста у уџбенику, дала К. Кончаревић:

1. Текстови са доминантном образовном функцијом - теоријско-спознајни текстови (TCT): припадају категорији научних текстова, развијају лингвистичку компетенцију;

2. Текстови са доминантном комуникативном функцијом - инструментално-практични текстови (ИПТ): функција им је комуникативна, информативна и лингвокултуролошка, понекад васпитна; 
3. Текстови са доминантном развијајућом функцијом - инструктивни текстови: развијају навике самосталног рада, нуде упутства и готове алгоритме, који се односе на сам поступак учења, објашњавају зашто и како треба учити, - и проверити; могу садржати имплицитну лингвокултуролошку информацију (у анализираном корпусу уџбеника ова могућа конструкцијска решења нису искоришћена).

Према тематској и жанровској припадности, К. Кончаревић даје поделу која обухвата следеће врсте текстова: литерарне епске, литерарне лирске, литерарне драмске текстове, авантуристичке приче, ученичке саставе, песме за певање (дечје, народне, шансоне), стрипове, рекламне текстове, текстове-инструкције (рецепти, упутства за употребу и сл.), текстове-документе, текстове-информације (обавештења, позивнице и сл.), интервјуе, научнопопуларне, информативно-публицистичке, текстове из свакодневног живота, басне, загонетке, анегдоте и енигматске прилоге (Кончаревић 1997: 217-218). ${ }^{3}$

За наше истраживање од највећег је значаја третман лингвокултуролошких текстова (ЛКТ). Кончаревић, имајући у виду да су лингвокултуролошки задаци наставе саставни део образовног циља наставе и да се у оваквим текстовима ученицима предочава систем чињеница, представа и генерализација везаних за цивилизацију народа чији се језик учи, сматра да постоји доста аргумената за њихово сврставање у ТСТ. Ипак, К. Кончаревић ЛКТ третира као ИПТ, наводећи њихове одлике:

1) за разлику од ТСТ који су писани у жанру научне прозе, ЛКТ су углавном публицистичког и књижевно-уметничког карактера, а у погледу стила одговарају неутралном (општекњижевном), публицистичком и разговорном регистру; категорија научних текстова лингвокултуролошке садржине у уџбеницима налази слабу примену, пошто се настоји да ови материјали на ученике делују не само рационално, већ и емоционално и естетски; примарна функција ЛКТ је комуникативна: њихов језички, говорни, екстралингвистички и евентуално фабуларни садржај, служи као основа за развијање навика и умења у рецептивним, продуктивним и секундарним говорним делатностима, док се лингвокултуролошке чињенице садржане у њима памте на нивоу локалних асоцијација;

б) ТСТ обликују се и на матерњем и на страном језику, за разлику од ЛКТ, реализованих на страном језику, што је такође потврда њихове доми-

3 И. Росандић нуди сличну поделу и по тематско-жанровском критеријуму издваја 20 врста текстова у уџбеницима страног језика и то: литерарне епске, лирске и драмске текстове, детективске приповетке, ученичке саставе, углазбљене песме, текстове стрипа, рекламе, рецепте, упутства, сведочанства, текстове из календара, позивнице, информације и извештаје о себи, о неком трећем лицу, појавама, догађајима и сл., интервјуе, свакодневне разговоре, научне, научнопопуларне текстове и телевизијске прилоге (Росандић 1988: 129-139). 
нантне комуникативно-функционалне усмерености; ТСТ са културном тематиком могли би се обликовати на матерњем језику, чиме би допринели интелектуализацији уџбеничких садржаја, уз истовремено стимулативно деловање (Кончаревић 2002: 93-94). Ова могућност, нажалост, није искоришћена у уџбеничком корпусу који смо истраживали - нисмо пронашли примере теоријско-спознајних текстова на матерњем језику.

Арутјунов говори о информацијском садржају наставног материјала са тачке гледишта очекивања ученика и потреба друштва. Садржај било ког вида комуникације на страном језику могу чинити информације о страној земљи, информације о земљи ученика и размена информација међунационалног карактера које нису везане за стварност страног или матерњег језика. Аутори уџбеника планирају шта је неопходно, корисно и занимљиво да ученик сазна о страној земљи и шта му је важно да саопшти о својој земљи, ,да би се осећао као равноправни партнер носиоца језика“. Чињенице матерње културе имају своје оправдање уколико служе остварењу одређених циљева: адекватном поимању стварности стране културе, разумевању правила и норми вербалног и невербалног понашања у страној земљи, омогућавају да се комуникација врши на материјалу матерње културе по аналогији са чињеницама матерње културе. (Арутюнов 1987: 52-54).

Саопштење према Арутјунову укључује три врсте информација и то су:

1) Предметна информација (због чега се нешто саопштава). То је објекат (тема) говора, оно најопштије што се садржи у тексту, преводу или перифрази. Предметна информација је главни објекат усвајања и обучавања, садржај наставне, професионалне, свакодневне и културне комуникације.

2) Пратећа информација (како је уобичајено говорити о овом или оном предмету у култури страног језика). То су, на пример, формуле етикеције, клиширане конвенционалне фразе, стереотипи; карактеристични начин изражавања пратеће информације је невербални језик (гестови, мимика, покрети очију, додир).

3) Фонска информација (ита треба знати о култури земље чији се језик учи да би се правилно примило и пренело саопштење). Састоји се од података којима влада просечни представник културе дате земље (у нашем случају просечно дете одговарајућег узраста - примедба наша).

Упоређујући однос предметне, пратеће и фонске информације у наставним материјалима, аутори долазе до сразмере $1>2>3$ (Арутюнов 1987: 56-57).

Типологија ЛКТ. Черњавска предлаже следеће критеријуме за поделу текстова са становишта њихове лингвокултуролошке вредности и могућности остваривања лингвокултуролошких циљева наставе: 1) порекло 
текста и 2) начин исказивања лингвокултуролошке информације у тексту (Чернявская 1983: 7).

а) Према пореклу текста издвајамо: наменски конструисане текстове и оригиналне ЛКТ. Према одређењу Черњавске, у конструисаним текстовима „,аутори свесно планирају садржај, обим и карактер културолошке информације, коју они уводе у текст, а такође могућности њене даље интерпретације у уџбенику и наставном процесу“. Под оригиналним текстовима подразумевамо аутентична вануџбеничка остварења различитих функционалних стилова и жанрова, али културолошки релевантна (Чернявская 1983: 7).

б) Материјал текстотеке, на основу начина изражавања културолошки значајне информације, делимо на: експлицитно културолошке текстове и имплициттно културолошке текстове (Чернявская 1983: 7) или, у терминологији Верешчагина и Костомарова, прагматичне и пројективне текстове (Верещагин, Костомаров 1983: 148-151). Ради се о терминологији са идентичним значењем (у даљем излагању користићемо само термине Т. Н. Черњавске ради економичнијег коришћења простора). У експлицитне ЛКТ уврстили смо текстове у којима се информација, релевантна са становишта културе, износи директно, у виду рационално-логичког исказа, тако да је адресат прима непосредно, а не на основу контекста или подтекста. Под имплицитно ЛКТ подразумевају се текстови у којима су на посредан начин садржане културолошки значајне информације: да би дошао до ње ученик мора да уложи одређени напор и открије је. На основу анализе уџбеничке продукције Черњавска закључује да је већина оригиналних текстова имплицитно културолошка, а конструисани текстови могу бити и експлицитно и имплицитно културолошке природе (Чернявская 1983: 8). Овај налаз Т. Н. Черњавске потврђује К. Кончаревић, закључивши да су оригинални текстови већи носиоци културолошки значајне информације, међу њима су присутни експлицитно културолошки (информативно-публицистички, научнопопуларни, текстови преузети из специјалних лингвокултуролошких и других приручника за учење руског језика) и имплицитно културолошки текстови (углавном књижевно-уметнички) (Кончаревић 1997: 454-456).

в) Према Арутјунову, на основу предмета саопштень, односно опредељења за статично (опис), динамично (наращију) или узрочно-последично излагање (расправа, аргументовање) ЛКТ сврставали смо у дескриптивне, наративне и аргументацијске (Арутюнов 1990: 77).

г) Черњавска издваја, према Верешчагину и Костомарову, и допунске критеријуме:

1) обим и тематска засићеност (велики, средњи, мали);

2) ниво апстракције у осветљавању културолошке теме (самостални и појашњавајући); 
3) жанр - монолошки: обавештење, есеј, чланак, прича, дневник, писMO;

- дијалошки: кратки ситуативни дијалог, сижејни дијалог, дијалог-нарација и дијалог-коментар; (Чернявская 1983: 21).

Кратки ситуативни дијалози, да би имали лингвокултуролошку вредност, морају адекватно одражавати чињенице и појаве савремене реалности, представљати типичне комуникативне ситуације и имати узуалну веродостојност. Сижејни дијалози имитирају реално говорно општење носилаца језика и имплицитно садрже лингвокултуролошке информације. Дијалози-нарације и дијалози-коментари експлицирају линвокултуролошке податке. Увођење културолошких података у експлицитној или имплицитној форми не сме нарушавати услове природне комуникације. Типичне ситуације информационе неједнакости сабеседника погодне за ове дијалоге су: дијалог Руса са странцем, екскурзија, интервју, разговор наставника са ученицима и сл. (Чернявская 1983: 13).

Оригинални текстови, према Черњавској, „намењени су носиоцима језика, члановима одређене културно-језичке заједнице, који су прошли социјализацију у једној култури и који владају заједничким фондом фонских знања“ (Чернявская 1983: 15). Ако се наведена чињеница има у виду, начин представљања оригиналних текстова у уџбеницима мора обезбедити ученицима фонска знања, неопходна за адекватно разумевање текста. Најзаступљенији и најразрађенији начин методичке интерпретације текстуалних материјала, са циљем извлачења из њих лингвокултуролошке информације и осигуравања њеног адекватног прихватања код ученика, јесте коментар. Лингвокултуролошки коментар (ЛКК) није самостални, већ појашњавајући текст: „он истиче, интерпретира, допуњава, систематизује и проширује културолошку информацију, присутну у другим наставним материјалима уџбеника“ (Чернявская 1983: 17). ЛКК може да се односи на речи, фразеологизме, афоризме, појаве етикеције, одломак, текст у целини, лингвокултуролошку тему... По обиму коментар може бити јединични (семантизује једну чињеницу) и комплексни (појашњава низ појава и чињеница); на основу места на коме се налази: предтекстуални, притекстуални и посттекстуални; даје се на матерњем језику ученика, на страном језику, или на језику посреднику. ЛКК помаже читаоцу да разуме текст који прати и зато мора одговарати нивоу његове језичке компетенције и бити разумљив без икаквих допунских појашњења.

Квалитативни методички показатељи у анализи текстова темеље се на начелима избора текста и рада на тексту, а то су начело разноврсности, аутентичности, начело узимања у обзир ученикових знања о тексту у матерњем језику и начело међусобне повезаности текста и система вежби. Квантита- 
тивни показатељи одређују заступљеност претходно дефинисаних врста и типова текста (Росандић 1988: 129).

\section{Б) ЕМПИРИЈСКА АНАЛИЗА ТЕКСТОТЕКЕ ИЗ ДВЕЈУ УЏБЕНИЧКИХ СЕРИЈА.}

Б. 1. О - Орбита

Б. 2. $\mathrm{P}-$ Родничок

У анализи текстотеке одабраног корпуса уџбеника кренули смо од инвентаризације културолошких информација у текстовима и утврђивања квантитативног односа између културолошки релевантних и културолошки неутралних текстова у уџбеницима, питања удела културе стране земье, земье ученика, култура у контакту, култура трећих земаља, интернационалних и неутралних материјала. Затим смо пажњу усмерили на егзактне показатеље читљивости и тако одредили лингвистичку тежину ЛКТ, а онда смо прешли и на испитивање квалитативних одлика презентације културолошких и лингвокултуролошких чињеница, односно карактеризацију текстотеке према тематској и жанровској припадности, према пореклу текста, према начину на који се изражава културолошки маркирана информација и према предмету саопштења.

За јединицу анализе узет је текст као „било који део писменог или усменог монолошког говора, који се састоји од исказа повезаних узрочним, временским или месним односима “, онако како у свом моделу мултифакторалне квалитативне анализе чине Арутјунов, Трушина и Чеботарев. У текстове су убрајани и дијалози који имају карактер уводног, главног, пратећег или допунског текста (и нису у оквиру одељака „Вежбе“ и „Задаци“). Под културолошки релевантним текстовима (ЛКТ) подразумевамо текстове у којима је садржана одређена предметна, пратећа или фонска информација везана за културу (у најширем смислу) и лингвокултурологију, без обзира на дозу те информащије, односно на експлицитни или имплицитни карактер текстова. Културолошки неутралним текстовима припадају текстови без оваких информација и у њих смо уврстили све привидно културолошки маркиране текстове (текстови чији су ликови особе са руским именима, али који, осим тих имена, не дају друге културолошке информације). Имена која су блиска и позната српском ученику, нпр. Наташа, Миша..., не представљају довољно јако обележје културолошке маркираности текста, уколико нису праћена додатним подацима: ми смо у ЛКТ убројали текстове који поред имена ликова садрже патроним. 
Квантитативни аспекти. Руска култура доминира у свим анализираним уџбеницима, док је матерња култура у уџбеницима заступљена у распону од једног до пет текстова. Од укупно 12 уџбеника анализираног уџбеничког корпуса чак 5 уџбеника у оквиру текстотеке уопште не даје овакве садржаје (P-1, 2, 6 и О-1,2). Ретки су уџбеници који презентују интернационалну културу или културу трећих земаља што сматрамо разумљивим, имајући у виду циљеве и задатке наставе страног језика у основној школи и чињеницу да општа културолошка знања ученици стичу путем других наставних садржаја и канала. Можемо констатовати да су у три уџбеника превагу однели неутрални текстови: Р-1, 3, 7. У Р-7 овакву слику добијамо због високе заступљености микродијалога који су у функцији допунских, односно пратећих текстуалних материјала, док је налаз за Р-1 и Р-3 такође оправдан, ако се узме у обзир узраст ученика и наглашена оријентација у правцу стицања комуникативне компетенције.

ТИПОВИ ТЕКСТОВА - БРОЈ (\%)

\begin{tabular}{|cccccccc} 
УЏБЕНИК & Р & С & РС & Р- треће & ТРЕЋЕ & ИНТЕР. & НЕУТР. \\
Р-1 & $32(38,55)$ & 0 & 0 & 0 & 0 & 0 & $51(61,44)$ \\
\hline P-2 & $36(64,28)$ & 0 & $4(7,14)$ & 0 & 0 & 0 & $16(28,57)$ \\
\hline P-3 & $20(34,48)$ & $1(1,72)$ & 0 & 0 & 0 & 0 & $37(63,79)$ \\
\hline P-4 & $32(80)$ & $2(5)$ & 0 & 0 & 0 & 0 & $6(15)$ \\
\hline P-5 & $26(52)$ & $1(2)$ & $1(2)$ & $2(4)$ & $2(4)$ & $2(4)$ & $16(32)$ \\
\hline P-6 & $47(54,02)$ & 0 & $1(1,14)$ & $1(1,14)$ & 0 & 0 & $38(43,67)$ \\
\hline P-7 & $23(34,84)$ & $5(7,57)$ & 0 & 0 & 0 & 0 & $38(57,57)$ \\
\hline P-8 & $34(48,57)$ & $3(4,28)$ & $1(1,42)$ & $1(1,42)$ & $1(1,42)$ & $3(4,28)$ & $27(38,57)$ \\
\hline O-1 & $31(62)$ & 0 & $4(8)$ & 0 & 0 & 0 & $15(30)$ \\
\hline O-2 & $31(81,57)$ & 0 & $2(5,26)$ & 0 & 0 & 0 & $5(13,15)$ \\
\hline O-3 & $33(56,89)$ & $5(8,62)$ & $2(3,44)$ & 0 & 0 & $4(6,89)$ & $14(24,13)$ \\
\hline O-4 & $28(60,86)$ & $1(2,17)$ & $1(2,17)$ & $1(2,17)$ & 0 & $3(6,52)$ & $12(26,08)$
\end{tabular}

Табела 1: Заступљеност културолошки релевантних и неутралних текстова ${ }^{4}$

4 Скраћенице:

$\mathrm{P}$ - текстови оријентисани према руској националној култури;

$\mathrm{C}$ - текстови оријентисани према српској националној култури;

$\mathrm{P}$ - C - текстови оријентисани према руско-српском интеркултурном дијалогу;

$\mathrm{P}$ - треће - текстови оријентисани према интеркултурном дијалогу руске и култура трећих земаља;

TPEЋЕ - текстови оријентисани према култури трећих земаља; 
Тематски аспекти ЛКТ. Анализирани уџбенички корпус обухвата широк спектар предметних информација које се издвајају на нивоу тематике ЛКТ:

Из руске културе: Русија, држава и географски положај, знаменитости и природне лепоте Русије; клима у Русији; биљни и животињски свет Русије, Сибир, градови Русије и њихове знаменитости (Москва, Подмосковље; Санкт-Петербург, Златни прстен Русије и др.); симболи Русије; грб, застава и химна Русије; развој руске железнице; саобраћај у Русији; градски превоз; историја; руско село; породица; свакодневни живот руских вршњака и одраслих; ентеријер руске куће, национална кухиња (традиционална јела; воће, поврће); одмор и слободно време руске деце, активни одмор у Русији; дечје организације; спорт, спортска такмичења, објекти, спортисти и њихови успеси; школа; руски систем образовања; здравствени систем; телевизија; научнотехничка достигнућа; освајање космоса; знамените личности руске историје, науке и културе; књижевност; дечја књижевност; руска традиција и обичаји; народно стваралаштво; културолошка ономатопеја; народна ношња; народно занатство; празници (Дан знања, Дан учитеља, имендан, рођендан, Татјанин дан, Нова година, Бадње вече, Божић, Масленица, Дан жена, Дан Русије, Дан Победе, Ускрс...); културни живот: културне манифестације, позориште, филм, музеји, музика; циркус.

Из националне културе ученика: наша земља (екскурзија по Србији), главни град и знаменитости; позориште; филм; музеји; телевизија; школа и школски живот; систем образовања; традиција и обичаји; празници (рођендан, Детинци, Материце, Оци, Бадње вече, Божић, Ускрс...); српско село; породица; знамените личности.

Не налазимо текстове које дотичу тему друштвеног и политичког уређења Русије, а из искуства нам се чини да то веома занима ученике. Показани приступ избору тема оправдан је са становишта психолошке примерености и комуникативне сврсисходности.

У уџбеницима Р-1, 2, 3 и О-1, 3, 4 преовладавају монолошки текстови, у Р-5, 6, 7, 8 и О-2 заступљенији су дијалошки, док су само у Р-4 превагу однели комбиновани текстови. Задовољавајући је налаз по коме у првим годинама учења језика не доминирају дијалошки текстови, пошто је експерименталним путем утврђено да су дијалошки текстови најсложенији за аудитивну рецепцију (Кончаревић 1997: 225)5.

ИНТЕР. - текстови оријентисани према интернационалној култури; НЕУТР. - културолошки неутрални текстови.

5 К. Кончаревић је користила материјал из (Елухина, Мусницкая 1978: 34). 


\begin{tabular}{ccccccc}
\hline & Монолошких & \multicolumn{3}{c}{ Дијалошких } & \multicolumn{3}{c}{ Комбинованих } \\
УџБЕНИК & $\begin{array}{c}\text { број } \\
\text { текстова }\end{array}$ & $\%$ & $\begin{array}{c}\text { број } \\
\text { текстова }\end{array}$ & $\%$ & $\begin{array}{c}\text { број } \\
\text { текстова }\end{array}$ & $\%$ \\
\hline P-1 & 20 & 62,50 & 4 & 12,50 & 8 & 25 \\
\hline Р-2 & 28 & 70 & 4 & 10 & 8 & 20 \\
\hline Р-3 & 15 & 71,42 & 4 & 19,04 & 2 & 9,52 \\
\hline Р-4 & 13 & 38,23 & 6 & 17,64 & 15 & 44,11 \\
\hline Р-5 & 12 & 35,29 & 13 & 38,23 & 9 & 26,47 \\
\hline Р-6 & 19 & 38,77 & 22 & 44,89 & 8 & 16,32 \\
\hline Р-7 & 9 & 32,14 & 16 & 57,14 & 3 & 10,71 \\
\hline Р-8 & 15 & 34,88 & 24 & 55,81 & 4 & 9,30 \\
\hline О-1 & 17 & 48,57 & 9 & 25,71 & 9 & 25,71 \\
\hline О-2 & 15 & 45,45 & 16 & 48,48 & 2 & 6,06 \\
\hline О-3 & 29 & 65,90 & 11 & 25 & 4 & 9,09 \\
\hline О-4 & 21 & 61,76 & 10 & 29,41 & 3 & 8,82 \\
\hline
\end{tabular}

Табела 2: Заступљеност ЛКТ (дијалошких, монолошких и комбинованих)

Испитивали смо лингвистичку тежину ЛКТ и, на основу егзактних показатеља читљивости према скали Ренате Шулц и пратећег апарата валоризације, израчунали смо индекс читљивости за сваки текст и уџбеник и представили налаз табеларно (Кончаревић 1997: 213). Поступак мерења састојао се у следећем: избројали смо укупни број речи, реченица и дугих речи (преко седам словних места) у сваком тексту, који смо означили као културолошки релевантан (из свих анализираних уџбеника) ${ }^{6}$, затим смо израчунали просечну дужину реченице тако што смо поделили укупан број речи са укупним бројем реченица и, према наведеној формули, израчунали индексе читљивости и затим их представили табеларно. Закључили смо да су добијене вредности сасвим задовољавајуће, индекс читљивости одговара нивоу учења језика и расте са увећањем нивоа комуникативне компетенције и са узрастом ученика. На појединим ЛКТ упутно би било спровести адаптацију, с обзиром на то да постоје тешкоће при њиховој визуелној перцепцији и озвучавању у периоду када код ученика почиње да се изграђује техника читања на страном језику. Збирну табелу за сваки уџбеник са укупним бројем

6 Осим уџбеника Р-1, 2 (због обимности укупног материјала нисмо спровели истраживање на њима, сматрамо и да културолошки аспекат предбукварског периода наставе треба засебно обрадити). 
ЛКТ разврстаних према скали по тежини - индексу читљивости дајемо на овом месту.

\section{УЏБЕНИК}

Текстови

$\begin{array}{lllllllllll}\text { Крајње лаган текст } & 4 & 5 & 11 & 19 & 5 & 3 & 11 & 15 & 14 & 14\end{array}$

$\begin{array}{lllllllllll}\text { Врло лаган текст } & 15 & 12 & 13 & 7 & 20 & 9 & 13 & 12 & 15 & 5\end{array}$

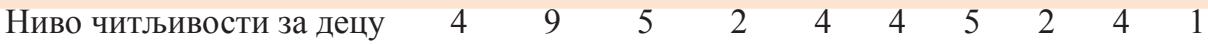
и омладину

$\begin{array}{lllllllllll}\text { Лаган текст } & 4 & 9 & 2 & 5 & 5 & 9 & 10 & 2 & 0 & 0\end{array}$

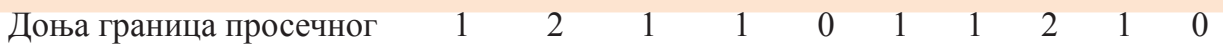
текста

$\begin{array}{lrlllllllll}\text { Просечан текст } & 1 & 7 & 1 & 1 & 7 & 2 & 3 & 1 & 0 & 0\end{array}$

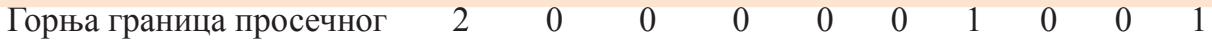
текста

$\begin{array}{lllllllllll}\text { Доња граница тешког } & 1 & 0 & 0 & 0 & 1 & 0 & 1 & 0 & 0 & 0\end{array}$ текста

Тежак тест

$\begin{array}{lllllllllll}\text { Горња граница тешког } & 0 & 0 & 0 & 0 & 0 & 0 & 1 & 0 & 0 & 0\end{array}$ текста

Врло тежак тест

$\begin{array}{llllllllll}1 & 0 & 0 & 0 & 0 & 0 & 0 & 0 & 0 & 0\end{array}$

Табела 3: Заступљеност ЛКТ према лингвистичкој тежини

a) Текстотеку смо анализирали са становишта порекла текста, табела број 4 приказује добијене резултате. Најзаступљенији су конструисани текстови који спадају у ред експлицитно или имплицитно ЛКТ.

\begin{tabular}{ccccccc}
\multirow{2}{*}{ УЏБЕНИК } & \multicolumn{2}{c}{ Конструисаних } & \multicolumn{2}{c}{ Адаптираних } & \multicolumn{2}{c}{ Оригиналних текстова } \\
\cline { 2 - 7 } & број & $\%$ & број & $\%$ & број & $\%$ \\
P-1 & 15 & 46,87 & 0 & 0 & 17 & 53,12 \\
\hline P-2 & 12 & 30 & 0 & 0 & 28 & 70 \\
\hline P-3 & 5 & 23,80 & 3 & 14,28 & 13 & 61,90 \\
\hline P-4 & 13 & 38,23 & 1 & 2,94 & 20 & 58,82 \\
\hline P-5 & 19 & 55,88 & 4 & 11,76 & 11 & 32,35 \\
\hline P-6 & 32 & 65,30 & 8 & 16,32 & 9 & 18,36 \\
\hline P-7 & 25 & 89,28 & 2 & 7,14 & 1 & 3,57 \\
\hline P-8 & 35 & 81,39 & 2 & 4,65 & 6 & 13,95 \\
\hline O-1 & 23 & 65,71 & 0 & 0 & 12 & 34,28
\end{tabular}


Слободанка Ж. Марковић: КУЛТУРОЛОШКИ И ЛИНГВОКУЛТУРОЛОШКИ АСПЕКАТ ...

\begin{tabular}{ccccccc}
\hline O-2 & 22 & 66,66 & 0 & 0 & 11 & 33,33 \\
O-3 & 29 & 65,90 & 3 & 6,21 & 12 & 27,27 \\
O-4 & 22 & 64,70 & 5 & 14,70 & 7 & 20,58
\end{tabular}

Табела 4: Аутентичност ЛКТ

$\begin{array}{lllllllllllll}\text { УЏБЕНИК Р-1 } & \text { P-2 } & \text { P-3 } & \text { P-4 } & \text { P-5 } & \text { P-6 } & \text { P-7 } & \text { P-8 } & \text { O-1 } & \text { O-2 } & \text { O-3 } & \text { O-4 }\end{array}$

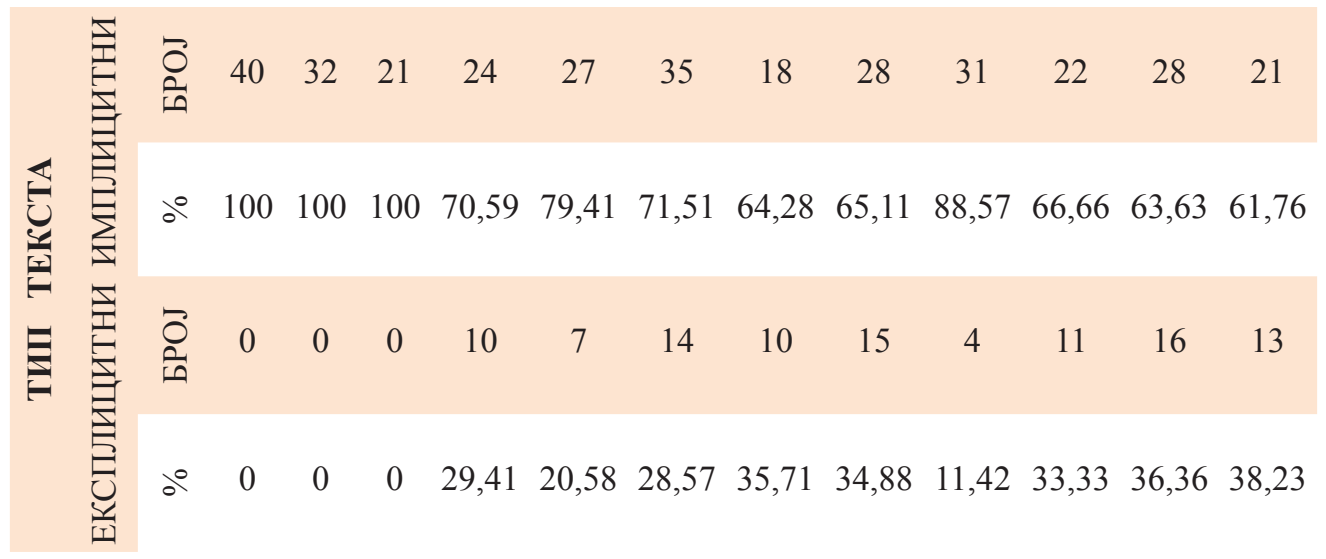

Табела 5: Заступљеност експлицитних и имплицитних културолошких текстова

б) Према критеријуму начина на који се изражава културолошки маркирана информација у табели број 5 приказујемо квантитативни однос између експлицитно и имплицитно ЛКТ.

Три уџбеника: Р-1, 2, 3 садрже искључиво имплицитни тип текста, док је и у осталим уџбеницима проценат имплицитних текстова изнад $60 \%$. При анализи ЛКТ по овом критеријуму запажамо јасно изражену законитост, да се у уџбеницима повећава број експлицитно ЛКТ од млађих ка старијим разредима - три уџбеника из серије Родничок их уопште не садрже: P-1, 2, 3; најнижи проценат експлицитно ЛКТ у серији Орбита јесте у уџбенику за прву годину учења - O-1: 11,42\%, а највиши у О-4 - уџбенику за четврту годину учења језика: $38,23 \%$.

в) Према предмету саопштења ЛКТ смо сврставали у дескриптивне, наративне или аргументацијске и запазили да превагу односе наративни текстови: највиши удео имају у уџбеницима за прве године учења језика (Р-3, 4, O-1); њихова заступљеност опада са повећањем нивоа знања, али остају доминантни. Приметан је и пораст удела најмање заступљених аргументацијских текстова: највиши удео имају у завршним годинама учења (O-4, Р-8). 


\begin{tabular}{|c|c|c|c|c|c|c|}
\hline \multirow[t]{2}{*}{ УЏБЕНИК } & \multicolumn{2}{|c|}{ Дескриптивних } & \multicolumn{2}{|c|}{ Наративних } & \multicolumn{2}{|c|}{$\begin{array}{c}\text { Аргументацијских } \\
\text { текстова }\end{array}$} \\
\hline & број & $\%$ & број & $\%$ & број & $\%$ \\
\hline$P-3$ & 7 & 33,33 & 14 & 66,66 & 0 & 0 \\
\hline P-4 & 7 & 20,58 & 23 & 67,64 & 2 & 5,88 \\
\hline P-5 & 11 & 32,35 & 19 & 55,88 & 4 & 11,76 \\
\hline P-6 & 15 & 31,91 & 24 & 51,06 & 8 & 17,02 \\
\hline P-7 & 7 & 25 & 14 & 50 & 7 & 25 \\
\hline P-8 & 13 & 30,23 & 21 & 48,83 & 9 & 20,93 \\
\hline O-1 & 11 & 31,42 & 23 & 65,71 & 1 & 2,85 \\
\hline $\mathrm{O}-2$ & 10 & 30,30 & 19 & 57,57 & 4 & 12,12 \\
\hline $\mathrm{O}-3$ & 18 & 40,90 & 21 & 47,72 & 5 & 11,36 \\
\hline $\mathrm{O}-4$ & 10 & 29,41 & 16 & 47,05 & 8 & 23,52 \\
\hline
\end{tabular}

Табела 6: Заступљеност дескриптивних, наративних и аргументацијских ЛКТ

\section{В) ЗАКЉУЧНА РАЗМАТРАЬА О МАТЕРИЈАЛУ ТЕКСТОТЕКЕ}

Наше истраживање потврдило је претпоставку да уџбенички текст представља базичну категорију теорије уџбеника. ЛКТ имају одлике ИПТ, по карактеру су публицистички и књижевно-уметнички, врше комуникативну функцију и обликовани су на руском језику. Чињенице страног језика и културе ученици усвајају контрастивно - путем аналогије или уочавањем разлика и трансфером већ усвојеног знања на нове чињенице. Уџбенички ЛКТ презентује три врсте информација: предметну, пратећу и фонску информацију. Издвојили смо најважније типологије и према њима смо вршили анализу текстуалних прилога на материјалу из двеју уџбеничких серија.

Квантитативни аспекти. Културолошки релевантни текстови преовладавају у серији Орбита, док су у серији Родничок присутни у пет уџбеника, у три уџбеника констатујемо превагу неутралних текстова: Р-1, 3, 7. Међутим, како заступљеност неутралних текстова није виша од $70 \%$ ни у једном од три наведена уџбеника, према ставу А. Арутјунова, који прихватамо, нећемо те уџбенике прогласити културолошки неутралним. Напоменућемо да су на исказани однос у Р-7 утицај имали кратки ситуативни, сижејни или наративни дијалози, које смо сврставали у текстове према критеријуму, јасно утврђеном на почетку истраживања, да текстуалним прилогом 
сматрамо било који део писменог или усменог монолошког или дијалошког говора, који се састоји од исказа, повезаних узрочним, временским или месним односима. Доминација неутралних текстуалних материјала у осталим уџбеницима, вероватно је последица вођења рачуна аутора о томе да се акултурација ученика не спроводи нагло на самим почецима учења језика, али и настојања, да се ученицима дају универзални садржаји у којима ће наћи препознатљиве и блиске ликове и фабуле које нису везане за одређену националну припадност и лоцираност. Закључујемо да је најнижи проценат ЛКТ у уџбеницима за прву годину учења језика, што потврђује изнети став. Према Арутјунову, примедба се може упутити само оним уџбеницима у којима је учешће ЛКТ, који се односе на руску културу испод $25 \%$, а таквих уџбеника у анализираном корпусу - нема. Идеални удео руске културе од 25 до 50\% имају уџбеници Р-1, 3, 5, 7, 8 и О-1, док остали уџбеници прелазе препоручену горњу границу у мањој мери (Р-2, 6 и O-3, 4, 1) или пак драстичније Р-4 и O-2 и према наведеном стандарду показују тенденцију нагле акултурације са могућим негативним ефектима. На основу нашег искуства у раду у школи, рекли бисмо да негативни ефекти у оваквим случајевима изостају.

Матерња култура у уибеницима. Од анализираних 12 уџбеника, пет уџбеника у оквиру текстотеке уопште не даје овакве садржаје, што сматрамо незадовољавајућим, имајући у виду основне теоријске ставове о значају комуникативне улоге ученика као даваоца саопштења. Оптимално присуство материјала из матерње културе од 15 до 25\% не налазимо, међутим, ако се у обзир узму и материјали везани за контакт руске и српске културе, повољној оцени најближи је уџбеник О-3. Руководећи се постављеним стандардом оптималне пропорције између страног, националног и неутралног од $3: 2: 1 \mathrm{ca}$ могућим одступањем од 20\%, као уџбеник „оријентисан на културе језика у контакту“, можемо издвојити О-3 и Р-5.

Проблематика интеркултурног дијалога представљена је у осам уџбеника, а четири уџбеника је не дотичу. Усмереност на културе језика у контакту не остварује се само идеалном пропорционалном заступљеношћу културолошких садржаја, значајно је инкорпорирање у текстуалне прилоге и материјале апаратуре организације усвајања (АОУ), дијалога између представника руске и матерње културе, који могу бити избалансирани (имају уједначену дужину реплика и дају уједначену дозу информације) и неизбалансирани (типа интервјуа, где један ученик тражи одговоре, други одговара и даје информације). Аутори анализираних уџбеника су доследно користили овакву могућност за презентацију лингвокултуролошких садржаја, нарочито у уџбеницима за више разреде, тако да наилазимо на више примера неизбалансираних дијалога у којима су углавном даваоци информација Руси, а примаоци информа- 
ција Срби (Разговор по чату перед Новым годом у О-4...); на 73. страни у Р-5, на пример, представљен је јединствен дијалог који говори о обичајима у Србији на Оие, Материце, Детинце и Бадње вече, а давалац информације је српско дете; у О-2 у дијалогу између руске и српске девојчице износе се подаци о Санкт Петербургу... Ређи су дијалози у којима учесници равноправно учествују у разговору (после посете Ермитажу, О-2), сазнају нове чињенице и износе раније научено...). Дијалоге, који би били барем приближно избалансирани, нисмо пронашли, али се оваква ситуација лако може надоместити преко АОУ: ако бисмо текстуалне и материјале АОУ посматрали обједињено, према важећем методичком начелу, заступљеност интеркултурног дијалога и саме матерње културе код појединих уџбеника би значајно порасла. Према нашој анализи, два уџбеника са највишим процентом удела руске културе у текстуалним прилозима (P-4, O-2) имају драстично нижи проценат заступљености лингвокултуролошких вежбања. Разлози наведеног односа могу бити у намери аутора да се језички материјал усваја на ЛКТ, а да саме лингвокултуролошке чињенице нису предвиђене за активно усвајање или су ЛКТ предвиђени за часове додатног рада, односно самостални рад код куће, будући да у преткомуникативним вежбањима културолошки релевантни садржаји преусмеравају пажњу ученика са саме језичке форме и операција са лингвистичким материјалом на информативни садржај, чиме се подстиче активност у изради вежбања.

На основу начина презентащије културолошке информащије идентификовали смо као најбројније краће ситуативне дијалоге чија је вредност у ситуацијској типичности, узуалној веродостојности и реалности на информацијском плану, затим сижејне дијалоге који имитирају реалну говорну комуникацију изворних говорника - имплицитно садрже одређене културолошки релевантне податке и дијалоге типа наращије или коментара са експлицираним културолошким подацима. Највећи проценат културолошки маркираних дијалошких текстова који су често у функцији главног текста налазимо у Р-8, 7, 6 и О-2, 3, 4.

Већина оригиналних текстова припада имплицитно културолошким, чиме потврђујемо изнети закључак анализе Черњавске и Кончаревић. Под оригиналним текстовима подразумевали смо аутентична вануџбеничка остварења различитих функционалних остварења и жанрова, али културолошки релевантна (ту смо сврстали аутентичне руске дечје разбрајалице блиске српској деци истог узраста, затим стихове, бајке и сл., познате просечном руском детету одговарајућег узраста). Њих је највише у уџбеницима за најмлађе ученике. Међу оригиналним текстовима присутни су и експлицитно културолошки и имплицитно ЛКТ. Према нашем налазу најмање је 
адаптираних текстова; четири уџбеника их уопште не садрже. Чињеница да је највиши удео конструисаних текстова, не мења наш општи закључак да текстотека из анализираног уџбеничког корпуса задовољава прописане критеријуме репрезентативности, веродостојности, актуелног историзма и савремености. ЛКТ дају ученицима такву информацију и у таквом виду, који је уобичајен у земљи носилаца језика, садржај и канали презентирања типични су за руску говорну средину. Текстови се презентују у интеракцији са акустичким и сликовним кодом, који су такође културолошки веродостојни и комуникативно аутентични (аудио-текстове интерпретирају изворни носиоци језика оба пола и одговарајуће старосне доби), начини презентације су разноврсни са становишта симулирања аутентичности (аутентични снимци телефонских разговора, навијачке атмосфере са стадиона, записа и обавештења са аеродрома, железничке и аутобуске станице, из метроа...). Утисак аутентичности остављају позивања на аутора или извор из кога је текст преузет, што је приметно у обема серијама. Навешћемо као илустрацију да је извор или аутор наведен у О-4: 8 пута, О-3: 20, Р-8: 5, Р-6: 8 пута итд.

Приказани однос експлицитно и имплицитно ЛКТ објашњавамо њиховим карактеристикама, будући да су први више апстрактни и имају сложенији језички израз за разлику од других, који су у том смислу пријемчивији ученику и омогућавају истовремено васпитно и емоционално деловање на ученика кроз одговарајуће материјале. Сматрамо да и први текстови делују на емоционалну, васпитну и, наравно, естетску страну, зато што могу код ученика изазвати осећања дивљења и радости, осећање лепог, али и жељу да оду у Русију - виде и доживе руску културу, осећање пријатељства и блискости са руским народом, руском земљом и културом. Удео експлицитних ЛКТ расте са узрастом и са увећањем комуникативне компетенције ученика, као и екстензитет и интензитет обраде културолошке тематике.

Водећи принцип структурисања параграфа у анализираном корпусу је тематски: тема параграфа обједињава главне, споредне и допунске ИПТ уџбеника, као и припадајући илустративни материјал и вежбања. У оквиру макроструктуре уџбеника теме се могу обједињавати по сродности и на тај начин градити шири тематски комплекси. Принцип презентације тема је линеарно-концентричан, што се огледа у чињеници да сваки разред обухвата садржаје из ужих тематских кругова претходних разреда. Поред вертикалне, приметна је и хоризонтална димензија, што значи да се одређени тематски комплекс из тематског круга лексике предвиђеног за дати разред обрађује на више места у уџбенику, тако да параграфи обрађују одређене исечке теме. Избор тема условљен је узрастом ученика, те у уџбеницима за ниже разреде налазимо најчешће информације о свакодневном животу деце, школи, 
играма и спорту, руском народном стваралаштву и стваралаштву познатих руских дечјих аутора (практично комуникативно усмерена настава у нижим разредима, посебно у току аудио-оралног курса), будући да су наведене теме у најужем кругу комуникативног минимума од почетне етапе. У вишим разредима културолошка тематика је комплекснија, разноврснија и свеобухватнија, одговара комуникативној компетенцији ученика. У анализираним уџбеницима први пут су присутни текстови у којима се обрађује религиозно-верска тематика: посета манастирима, Божић, Ускрс и др. У ранијим корпусима их није било, а значајни су, јер наглашавају српско-руске духовне и православне везе, упућују на дијалог култура.

Констатоваћемо да у свим уџбеницима превагу односе наративни текстови, што се позитивно оцењује, јер је у складу са препорукама методичара - највиши удео имају у уџбеницима за прве године учења језика, док њихова заступљеност опада са увећањем нивоа знања, мада остају доминанатни у односу на друге типове текста. Очекиван је и пораст удела најмање заступљених аргументацијских текстова: највиши удео имају у завршним годинама учења, што је разумљиво са психолошког становишта и утврђене лингвистичке неподесности ових текстова за млађи узраст, јер тек на стадијуму развоја апстрактног мишљења ученици могу да разумеју текстове у чијој је основи категорија каузалитета, односно извођење мисли једне из друге логичким следом.

За поједине текстове из уџбеника анализираног корпуса пожељна би била адаптација, али број таквих текстова на нивоу уџбеника није велики. Највећи број дугих речи садрже текстови у уџбеницима за више разреде и препорука је да се удео дугих речи смањи, зато што не смемо заборавити чињеницу да се техника читања још увек развија и да је ученицима тешко да перципирају и евентуално озвуче текст са великим бројем дугих речи. Подржавамо став К. Кончаревић да су и текстови на нивоу просечних, за ученике који руски језик уче тек другу или трећу годину доста амбициозни, јер они су просечни само за носиоце руског језика као матерњег. К. Кончаревић с правом сугерише ауторима да текстове из поменуте категорије ,упросте и адаптирају према нивоу комуникативне компетенције ученика“. Искуство аутора показује да се то може постићи без негативних последица по научност и методичност излагања (Кончаревић 2002: 111).

При диференцирању ЛКТ по методичкој тежини издвојили смо као лакше - наративне текстове са једном сижејном линијом, информативним планом који је психолошки близак ученику или познат из властитог искуства, са јасном структуром и композицијом, без много споредних детаља. У ову групу текстова уврстили смо све наративне текстове из уџбеника: Р-1, 2, 
$3,4,5$, и О-1, али и већину наративних текстова из Р-7, 8 и О-3, 4. Средње тешки су ЛКТ са већим информативним набојем, сложенијом структуром, већим бројем детаља, већом апстрактношћу и већим присуством логичког расуђивања, налазе се у Р-6, 7, 8 и О-2, 3, 4 и погодни су за развијање препричавања, дискусију, писање састава. Са становишта информативне засићености и примерености, ЛКТ углавном одговарају могућностима рецепције одређене узрасне групе; мали број текстова може бити окарактерисан као тежак због апстрактности или сложене композиције; извесна оптерећеност фактографијом уочава се, можда, у мањем броју ЛКТ у којима се потешкоће тичу великих количина информација које ограничавају ученике при репродуковању текста, наводећи их на пасивно запамћивање чињеница уз недовољно разумевање смисла, нпр.: Поездка на Север России... (О-3), По Золотому кольиу России,... (О-4), поједини прилози из рубрике Альбом путешественника и понекад Диалоги који следе иза уводног стрипа $(\mathrm{P}-8,7)$ или из рубрике Знаешь ли тыз? (Р-6).

Великим културолошким потенцијалом располаже ЛКК као појашњавајући текст који се односи на неку реч или израз из текста, на део текста или текст у целини. Он може бити на матерњем језику ученика или руском језику и мора бити разумљив без допунских појашњења. У анализираним уџбеницима идентификовали смо укупно 172 ЛКК и сви су на руском језику: 43 објашњавају одређене предметне или фонске информације, док је 129 усмерено на интерпретацију норми вербалног понашања, превасходно етикеције и лингвокултуролошког потенцијала номинационих јединица. Сматрамо да би кратки ЛКК, презентовани на српском језику, деловали изузетно подстицајно у првим годинама учења, када ученике треба посебно мотивисати и изградити позитиван и емоционални однос према руској култури. ЛКК се налазе углавном после текста, ређе их можемо наћи у предтекстуалној позицији као што је, нпр. у О-4 на 107. страни, где се у кратком ЛКК изнад песме Я шагаю по Москве, сазнаје о њеном пореклу и саопштава да данас тако звоне мобилни телефони многих Московљана. Присуство ЛКК о невербалном понашању ограничено је на два уџбеника из серије Орбита $(\mathrm{O}-3,4)$; серија Родничок их не садржи и ту констатацију можемо сматрати примедбом коју бисмо упутили ауторима.

ЛКТ обликовани су искључиво на руском језику, углавном имају парцијалне речнике, само у неким уџбеницима одређени број текстова (нпр. у O-3 у рубрици Традици и обычаи) нема никаквих лексичких објашњења, што указује на то да представљају додатно штиво предвиђено за самостални или додатни рад. 
Предметне информације представљене су веродостојно (нисмо нашли примере информационе нетачности), доследно су поштовани принципи савремености и актуелног историзма, већина ЛКТ приказује савремену руску културу у њеним најразличитијим облицима и манифестацијама, док се из прошлости узима само оно што је оставило дубљег трага и као такво познато је просечном носиоцу руског језика и културе. На одређену архаизацију и идеализацију наилазимо у уџбенику О-3, где се доста пажње посвећује тематици традиције и обичаја (стална рубрика Традиции и обычаи) и, евентуално, у мањој мери у O-4, P-4, 5, 6, 7 (традиционална јела, празници, обичаји, традиционалне руске игре, веровања, записи на брезовој кори).

Закључак на који нас упућује текстотека у анализираним уџбеницима јесте да је приступ анализираних уџбеника савремен, позитивно утиче на мотивацију, приближава руску културу носиоцима српског језика и српске културе. Анализирани текстуални материјали уџбеника пружају солидну основу за извођење културолошки оријентисане наставе језика.

\section{ЛИТЕРАТУРА}

Арутюнов, А. Р. (1987). Конструирование и экспертиза учебника. Москва: Русский язык.

Арутюнов, А. Р., Трушина, Л. Б., Чеботарев, П. Г. (1981). “Многофакторный количественный анализ учебников иностранных языков“, у Сборник статей, сост. Трушина, Л. Б. (Москва: Русский язык): 58-76.

Верещагин, Е. М., Костомаров, В. Г. (1983). Язык и культура. Лингвострановедение в преподавании русского языка как иностранного. Москва: Русский язык.

Верещагин, Е. М., Костомаров, В. Г. (1981). “О лингвострановедческом аспекте учебника“, Сборник статей, сост. Трушина, Л. Б. (Москва: Русский язык): 154-170.

Зујев, Д. Д. (1988). Школски уибеник. Београд: Завод за уџбенике и наставна средства.

Кончаревић, К. (1997). Структура и садржај уибеника руског језика за основну школу (докторска дисертација). Београд: Филолошки факултет (дактилографисани рукопис).

Кончаревић, К. (2002). Савремени уибеник страног језика: структура и садржај. Београд: Завод за уџбенике и наставна средства.

Rosandić, I. (1988). Tekst u nastavi njemačkog kao stranog jezika. Doktorska disertacija. Zagreb: Filozofski fakultet. 
Чернявская, Т. Н. (1983). Приёмы создания и использования текстовых материалов учебника русского языка для иностранцев в лингвострановедческих целях. Москва: Институт русского языка им. Пушкина.

\section{Slobodanka Marković \\ CULTURAL AND LINGUISTIC-CULTURAL ASPECTS OF THE TEXTS IN PRIMARY SCHOOL TEXTBOOKS AND WORKBOOKS FOR THE RUSSIAN LANGUAGE}

\section{Summary}

This paper analyzes relevant textual materials with cultural content in current primary school textbooks for the Russian language. At first we identified linguistic-cultural texts (LCT) in all the analyzed textbooks and determined the relation between culturally neutral and culturally relevant texts. Next, we considered the issue of a foreign country's share, the share of the students' country, the content representing culture in contact, the culture of a third country and appendices with international values. Following this, we directed our attention to exact indicators of readability, thus determining the linguistic significance of LCTs, and then moved onto testing the qualitative features of the presentation of cultural and linguistic-cultural facts, with a reference to the character of texts in accordance with the theme and the genre, a method by which culturally marked information is expressed with respect to the origin of the text and the subject of the announcement.

We conclude that the author uses a modern approach; the textbooks strive to approach cultural values of Russia with credibility. They are rich in linguistic and cultural materials and different topics. For the first time LCTs with religious themes are present, which is significant for Serbian and Russian spiritual and orthodox connections and it points to a dialogue of the two cultures. The presumption that we started with is confirmed: with age and an increase in the communicative competence, the number of texts related to the cultural information also grows - most of them are in the textbooks for the $7^{\text {th }}$ and the $8^{\text {th }}$ grade, while the least number is present in the textbooks for lower grades. All text types that are found in the general textbook theory are observed.

Key words: textbook, text, culture, linguistic-cultural, transmission of culture, sociocultural competence. 